\title{
KEANEKARAGAMAN HYMENOPTERA PARASITOID PADA STURUKTUR LANSKAP PERTANIAN BERBEDA DI DAERAH ALIRAN SUNGAI (DAS) CIANJUR, JAWA BARAT
}

\author{
Yaherwandi $^{1}$, S. Manuwoto ${ }^{2}$, D. Buchori ${ }^{2}$, P. Hidayat ${ }^{2}$, dan L.B. Prasetyo ${ }^{3}$
}

\begin{abstract}
Diversity of Hymenoptera Parasitoid in Different Agricultural Landscape at Cianjur Watershed, West Java. Understanding how the landscape structure affect the interaction between crops, pests and their natural enemies is a complex problem that can significantly impact on the success or failur of insect biological control. Hymenoptera parasitoid are particularly important natural enemies because of their great diversity and effectiveness as agents of biological control. The objective of this research is to study the diversity of Hymenoptera parasitoid in rice field at Cianjur Watershed. Insects were sampled using three trapping techniques (farmcop, insect net and yellow pan trap). Species accumulative curves, Jackknife-1 estimator, indices of diversity, indices of community similarities and cluster analysis were applied to analyze the data. Results indicated that there were 2750 speciment consist of 26 family and 325 species of Hymenoptera parasitoid in rice fields at Cianjur Watershed. Diversity of Hymenoptera parasitoid were found to be influenced by the landscape structure and seasone of ricefield. Species richness and diversity were higher in Nyalindung landscape than Gasol and Selajambe landscape.
\end{abstract}

Key words: landscape structure, diversity, hymenoptera parasitoid, rice fields

\section{PENDAHULUAN}

Lanskap pertanian adalah sekumpulan ekosistem yang tidak hanya meliputi lahan pertanaman (agroekosistem) tetapi juga ekosistem diluarnya, seperti tumbuhan liar, jalan raya, perkampungan dan lainnya (Forman dan Godron, 1986). Pada lanskap pertanian moderen struktur spasial, keanekaragaman habitat dan komposisi habitat sangat bervariasi dari satu lanskap ke lanskap yang lain. Lanskap pertanian yang sangat sederhana misalnya, hanya terdiri atas satu jenis pertanaman (monokultur) dan tumbuhan liar, sedangkan lanskap pertanian yang kompleks tidak hanya terdiri atas berbagai pertanaman (polikultur), tetapi juga terdapat banyak tumbuhan liar.

Daerah Aliran Sungai (DAS) Cianjur adalah subsub DAS Citarum tengah yang terletak di Kabupaten Cianjur. DAS Cianjur merupakan suatu sistem yang khas bila ditinjau dari segi pengelolaan lanskap. DAS Cianjur dari hulu sampai ke hilir mempunyai struktur lanskap yang beragam. Desa Nyalindung misalnya terletak di bagian hulu DAS Cianjur mempunyai 12 kelas elemen lanskap dan 30 patch membentuk struktur lanskap yang kompleks, sedangkan Gasol yang terletak di bagian tengah mempunyai enam kelas elemen lanskap dan 28 patch dan Selajambe yang terletak di bagian hilir mempunyai tiga kelas elemen lanskap dan 13 patch membentuk struktur lanskap yang lebih sederhana (Yaherwandi et al., 2006). Ditinjau dari teori ekologi lanskap maka struktur dasar ketiga lanskap tersebut yaitu; (1) matriks (matrix) adalah pertanaman padi, (2) bidang lahan (patch) yaitu pemukiman, kebun campur, pertanaman sayur, palawija dan lahan bera, dan (3) koridor (corridor) berupa pematang sawah dan pinggiran saluran irigasi (Yaherwandi et al., 2006). Ketiga struktur dasar lanskap ini merupakan habitat yang dapat dihuni serangga hama dan musuh alami.

Van Emden (1991) menyatakan peningkatan keanekaragaman habitat dalam lanskap pertanian dapat meningkatkan keanekaragaman serangga hama dan serangga bermanfaat dan seringkali kerusakan tanaman oleh hama berkurang. Selanjutnya Kruess dan Tscharntke (2000) menambahkan bahwa tipe dan kualitas habitat, susunan spasial dan keterhubungan (connectivity) antar habitat di dalam suatu lanskap dapat mempengaruhi keanekaragaman hayati dan fungsi ekosistem. Hipotesis tersebut didukung oleh Marino dan Landis (2000) yang mengemukakan bahwa keanekaragaman struktur lanskap pertanian tidak hanya mempengaruhi keanekaragaman musuh alami di dalam pertanaman, tetapi juga kelimpahan dan keefektifannya. Selanjutnya Kruess (2003) memperkuat hipotesis tersebut dengan mengemukakan hasil penelitiannya yaitu kekayaan

\footnotetext{
${ }^{1}$ Dosen Jurusan Hama dan Penyakit Tumbuhan Fakultas Pertanian Universitas Andalas, Kampus Limau Manis, Padang 25163

${ }^{2}$ Dosen Departemen Proteksi Tanaman Fakultas Pertanian Institut Pertanian Bogor

${ }^{3}$ Dosen Departemen Konservasi Sumberdaya Hutan Fakultas Kehutanan Instiut Pertanian Bogor
} 
spesies dan laju parasitisme parasitoid dari Melanogromyza aeneoventris (Diptera: Agromyzidae) meningkat dengan meningkatnya keanekaragaman habitat di dalam lanskap.

Kajian ekologi lanskap mencakup studi tentang struktur, interaksi antara komponen penyusun lanskap dan perubahan atau kerusakan habitat yang terjadi dalam lanskap (Forman dan Godron, 1986; Kruess dan Tscharntke, 1994) akan menjadi lebih bermakna apabila dikaitkan dengan keanekaragaman musuh alami, khususnya Hymenoptera parasitoid. Hal ini terutama disebabkan Hymenoptera parasitoid mempunyai keanekaragaman yang tinggi dan berperan penting dalam mengatur populasi alami serangga herbivor (LaSalle, 1993). Untuk itu telah dilakukan penelitian yang bertujuan untuk mempelajari pengaruh struktur lanskap terhadap keanekaragaman Hymenoptera parasitoid pada berbagai tipe lanskap pertanian di DAS Cianjur Jawa Barat.

\section{METODE PENELITIAN}

Pengambilan sampel serangga pada pertanaman padi dilakukan di desa Nyalindung (bagian hulu), Gasol (bagian tengah) dan Selajambe (bagian hilir) DAS Cianjur dari bulan Januari sampai November 2003. Masing-masing desa mempunyai struktur lanskap atau jenis penggunaan lahan yang berbeda. Deskripsi masing-masing lanskap tersebut disajikan pada Tabel 1.

Pelaksanaan Penelitian. Pada masing-masing lanskap dibuat dua jalur transek dengan panjang lebih kurang $1000 \mathrm{~m}$ atau sepanjang pertanaman yang ada, jarak antara transek 500 - $600 \mathrm{~m}$. Di sepanjang jalur transek ditentukan titik pengambilan sampel yang berjarak $100 \mathrm{~m}$, sehingga masing-masing transek terdapat 10 titik sampel, jadi ada 20 titik sampel setiap lanskap. Pengambilan sampel serangga dilakukan pada saat pertanaman padi berumur 20,50, 80 hari setelah tanam (hst) dan 1 minggu setelah panen. Hal ini berdasarkan pertimbangan keadaan pertanaman dan tingkat pertumbuhan tanaman padi di lapangan.

Pengambilan sampel serangga pada setiap titik sampel pada jalur transek dilakukan dengan menggunakan mesin penghisap serangga farmcop, jaring ayun dan nampan kuning. Farmcop terbuat dari mesin penghisap debu (vacum cleaner) yang dilengkapi dengan aki, kabel, selang dan wadah penampung serangga (Heong et al., 1991 dan Rizali et al., 2002). Pengambilan sampel serangga dengan farmcop dilakukan dengan menyungkup tanaman terlebih dahulu dengan kurungan kain kasa berbingkai (alas 50 x $50 \mathrm{~cm}$ dan tinggi $90 \mathrm{~cm}$ ), kemudian dihisap dengan farmcop selama 5 menit untuk setiap titik sampel (Heong et al., 1991)

Jaring ayun berbentuk kerucut, mulut jaring terbuat dari kawat melingkar berdiameter $30 \mathrm{~cm}$ dan jaring terbuat dari kain kasa. Pengambilan sampel serangga setiap titik sampel dilakukan dengan mengayunkan jaring ke kiri dan ke kanan secara bolak balik sebanyak 20 kali sambil berjalan.

Nampan kuning terbuat dari wadah plastik yang berukuran alas 15 x $25 \mathrm{~cm}$ dan tinggi $7 \mathrm{~cm}$. Nampan kuning diletakkan di tanah dan di tempat terbuka agar mudah terlihat oleh serangga. Nampan kuning digunakan untuk memerangkap serangga yang tertarik warna kuning. Sebelum nampan dipasang terlebih dahulu ke dalam nampan dimasukkan larutan air sabun. Air sabun digunakan untuk mengurangi tegangan permukaan, sehingga serangga yang masuk

Tabel 1. Deskripsi lokasi penelitian di Daerah Aliran Sungai Cianjur

\begin{tabular}{|c|c|c|c|}
\hline $\begin{array}{l}\text { Desa } \\
\text { /Lanskap }\end{array}$ & Koordinat/lokasi & Ketinggian & Jenis penggunaan lahan \\
\hline Nyalindung & $\begin{array}{l}06^{\circ} 47^{\prime} 22,7^{\prime \prime} \text { LS } \\
107^{\circ} 03 \text { '30,6” BT }\end{array}$ & 879-1010 m.dpl & $\begin{array}{l}\text { Padi polikultur, palawija, sayuran, kampung } \\
\text { dan kebun campur }\end{array}$ \\
\hline Gasol & $\begin{array}{l}06^{\circ} 48^{\prime} 17,0^{\prime \prime} \text { LS } \\
107^{\circ} 05^{\prime} 40,1 " \text { BT }\end{array}$ & $665-693$ m.dpl & $\begin{array}{l}\text { Padi monokultur, sedikit palawija dan } \\
\text { sayuran, kampung dan kebun campur }\end{array}$ \\
\hline Selajambe & $\begin{array}{l}06^{\circ} 48^{\prime} 09.0^{\prime \prime} \text { LS } \\
107^{\circ} 12^{\prime} 52,9^{\prime \prime} \mathrm{BT}\end{array}$ & $346-351$ m.dpl & Padi monokultur, kampung dan kebun campur \\
\hline
\end{tabular}

LS (lintang selatan), BT (bujur timur), m.dpl (meter di atas permukaan laut) 
akan tenggelam dan akhirnya mati. Setiap titik sampel dipasang satu nampan dan dibiarkan selama 24 jam. Serangga yang tertangkap dengan farmcop, jaring ayun dan nampan kuning dibersihkan dari kotoran. Selanjutnya disimpan dalam tabung film berisi alkohol $70 \%$ untuk diidentifikasi di laboratorium.

Identifikasi serangga dilakukan di Laboratorium Bioekologi Parasitoid dan Predator Departemen Hama dan Penyakit Tumbuhan Fakultas Pertanian, Institut Pertanian Bogor. Semua serangga yang diperoleh dipisahkan berdasarkan ordonya. Khusus bagi ordo Hymenoptera parasitoid, identifikasi dilanjutkan sampai tingkat famili dan morfospesies (hanya diberi kode). Selanjutnya morfospesies dalam tulisan ini ditulis spesies saja. Identifikasi serangga untuk tingkat famili dilakukan dengan mengacu buku Goulet dan Huber (1993)

Analisis Data. Keanekaragaman dan kelimpahan spesies Hymenoptera parasitoid dianalisis dengan menggunakan indeks keanekaragaman ShannonWiener, kemerataan spesies dianalisis dengan indeks kemerataan Simpson (Magurran, 1988; Spellerberg, 1995 dan Krebs, 1999). Untuk menghitung kekayaan spesies, indeks Shannon-Wiener dan indeks kemerataan Simpson digunakan program Ecological Methodology (Krebs, 2000). Untuk menentukan perbedaan masing-masing kekayaan, keanekaragaman dan kemerataan spesies Hymenoptera parasitoid digunakan analisis ragam (One way ANOVA) dan uji jarak berganda Duncan (DNMRT) 95\% menggunakan program Statistica 5.0 for Windows (StatSoft, 1997)

Untuk membuat kurva akumulasi spesies, jumlah spesies yang diperoleh pada setiap titik sampel diacak sebanyak 50 kali dengan program EstimateS 6.0b1 (Colwell, 2000). Dari hasil pengacakkan tersebut diperoleh nilai estimasi kekayaan spesies Hymenoptera parasitoid berdasarkan Jackknife-1 estimator (Colwell \& Coddington, 1994 dan Colwell, 2000).

Kemiripan komunitas Hymenoptera parasitoid pada ketiga lanskap dianaliis dengan mengunakan indeks kemiripan Sorensen. Untuk memperoleh nilai indeks kemiripan Sorensen digunakan program Biodiv97 yang diintegrasikan dalam Microsoft Exel. Selanjutnya dilakukan analisis pengelompokan komunitas dengan Cluster analysis (UPGMA) menggunakan program Statistica for Windows 5.0 (StatSoft, 1997).

\section{HASIL DAN PEMBAHASAN}

Total Jumlah Individu dan Spesies Hymenoptera Parasitoid. Jumlah keseluruhan Hymenoptera parasitoid yang telah dikumpulkan pada pertanaman padi di DAS Cianjur dalam priode Januari sampai dengan periode November 2003 adalah 2750 individu yang termasuk dalam 26 famili dan 325 spesies (Tabel 2). Jumlah famili yang telah dikumpulkan dalam penelitian ini jika dibandingkan dengan pertanaman padi di Filipina lebih sedikit yaitu 31 famili (Heong et al., 1991), tetapi jumlah itu lebih banyak dari yang pernah dilaporkan pada pertanaman padi di Yogyakarta yaitu 8 famili (Mahrub, 1998).

Dari 26 famili Hymenoptera parasitoid yang telah dikumpulkan, lima famili yaitu Braconidae, Diapriidae, Eulophidae, Ichneumonidae dan Scelionidae. adalah famili yang mempunyai spesies terbanyak (> 10 spesies) yang ditemukan pada lanskap Nyalindung, Gasol dan Selajambe. Jika berdasarkan kelimpahan relatif maka Braconidae, Encyrtidae, Diapriidae, Eulophidae dan Scelionidae merupakan famili yang kelimpahan relatifnya tertinggi (> 10\%) pada ketiga lanskap tersebut. Hasil penelitian ini mirip dengan yang dilaporkan Heong et al. (1991) dan Mahrub (1998) bahwa Braconidae, Diapriidae, Eulophidae, Ichneumonidae, Mymaridae, Pteromalidae, Scelionidae dan Trichogrammatidae merupakan famili yang dominan pada pertanaman padi. Hal ini karena sebagian besar spesies dari familifamili tersebut merupakan parasitoid dari serangga hama padi dari ordo Homoptera seperti wereng batang dan wereng daun dan ordo Lepidoptera seperti penggrek batang dan ulat pemakan daun (Heong et al., 1991; Mahrub, 1998).

Pendugaan Kekayaan Spesies Hymenoptera Parasitoid. Kurva akumulasi spesies Hymenoptera parasitoid pada ketiga lanskap masih menunjukan adanya peningkatan walaupun kenaikannya tidak terlalu tajam (Gambar 1). Tetapi jumlah spesies yang dikumpulkan pada ketiga lanskap telah mencapai $70 \%$ dari Hymenoptera parasitoid yang ada berdasarkan Jacknife-1 estimator (Gambar 2).

Menurut Krebs (1999) jumlah spesies tertinggi yang diestimasi oleh Jacknife estimator adalah dua kali jumlah spesies yang diperoleh. Selanjutnya dinyatakan bahwa Jackknife estimator dipengaruhi oleh total jumlah spesies, ukuran sampel 
Tabel 2. Jumlah famili, spesies, individu, dan kelimpahan relatif Hymenoptera parasitoid pada lanskap Nyalindung, Gasol dan Selajambe

\begin{tabular}{|c|c|c|c|c|c|c|c|c|c|}
\hline \multirow[b]{2}{*}{ Famili } & \multicolumn{3}{|c|}{ Nyalindung } & \multicolumn{3}{|c|}{ Gasol } & \multicolumn{3}{|c|}{ Selajambe } \\
\hline & JS & $\mathrm{JI}$ & KR & JS & JI & KR & JS & $\mathrm{JI}$ & $\mathrm{KR}$ \\
\hline Aphelinidae & 4 & 61 & 5,25 & 3 & 23 & 3,12 & 1 & 59 & 5,69 \\
\hline Bethylidae & 7 & 12 & 1,03 & 2 & 5 & 0,68 & 2 & 8 & 0,77 \\
\hline Braconidae & 25 & 95 & 8,18 & 17 & 88 & 11,92 & 16 & 63 & 6,08 \\
\hline Ceraphronidae & 12 & 31 & 2,67 & 7 & 17 & 2,30 & 5 & 14 & 1,35 \\
\hline Chalcididae & 2 & 4 & 0,34 & 2 & 2 & 0,27 & 7 & 7 & 0,68 \\
\hline Diapriidae & 21 & 51 & 4,39 & 20 & 76 & 10,30 & 18 & 148 & 14,27 \\
\hline Drynidae & 1 & 1 & 0,09 & 0 & 0 & 0,00 & 1 & 1 & 0,10 \\
\hline Elasmidae & 6 & 14 & 1,21 & 4 & 16 & 2,17 & 3 & 50 & 4,82 \\
\hline Encyrtidae & 12 & 154 & 13,26 & 8 & 61 & 8,27 & 9 & 127 & 12,25 \\
\hline Eucoilidae & 7 & 29 & 2,50 & 4 & 8 & 1,08 & 3 & 7 & 0,68 \\
\hline Eulophidae & 34 & 159 & 13,70 & 25 & 87 & 11,79 & 31 & 115 & 11,09 \\
\hline Eupelmidae & 2 & 9 & 0,78 & 0 & 0 & 0,00 & 2 & 7 & 0,68 \\
\hline Eurytomidae & 2 & 6 & 0,52 & 3 & 6 & 0,81 & 3 & 22 & 2,12 \\
\hline Ichneumonidae & 24 & 67 & 5,77 & 21 & 39 & 5,28 & 15 & 35 & 3,38 \\
\hline Mutilidae & 0 & 0 & 0,00 & 1 & 1 & 0,14 & 0 & 0 & 0,00 \\
\hline Mymaridae & 8 & 72 & 6,20 & 10 & 48 & 6,50 & 10 & 58 & 5,59 \\
\hline Mymarommatidae & 1 & 2 & 0,17 & 1 & 6 & 0,81 & 1 & 6 & 0,58 \\
\hline Platygastridae & 6 & 79 & 6,80 & 3 & 32 & 4,34 & 1 & 25 & 2,41 \\
\hline Pteromalidae & 3 & 15 & 1,29 & 6 & 8 & 1,08 & 4 & 33 & 3,18 \\
\hline Scelionidae & 36 & 207 & 17,83 & 32 & 172 & 23,31 & 36 & 171 & 16,49 \\
\hline Scoliidae & 1 & 1 & 0,09 & 0 & 0 & 0,00 & 0 & 0 & 0,00 \\
\hline Sierolomorphidae & 1 & 2 & 0,17 & 0 & 0 & 0,00 & 0 & 0 & 0,00 \\
\hline Signiphoridae & 3 & 50 & 4,31 & 2 & 29 & 3,93 & 2 & 21 & 2,03 \\
\hline Tetracampidae & 2 & 6 & 0,52 & 1 & 1 & 0,14 & 4 & 21 & 2,03 \\
\hline Tiphiidae & 1 & 1 & 0,09 & 0 & 0 & 0,00 & 0 & 0 & 0,00 \\
\hline Trichogrammatidae & 7 & 33 & 2,84 & 4 & 13 & 1,76 & 4 & 39 & 3,76 \\
\hline
\end{tabular}

Keterangan : JS = Jumlah Spesies

$\mathrm{JI} \quad=$ Jumlah Individu

$\mathrm{JR}=$ Jumlah Relatif

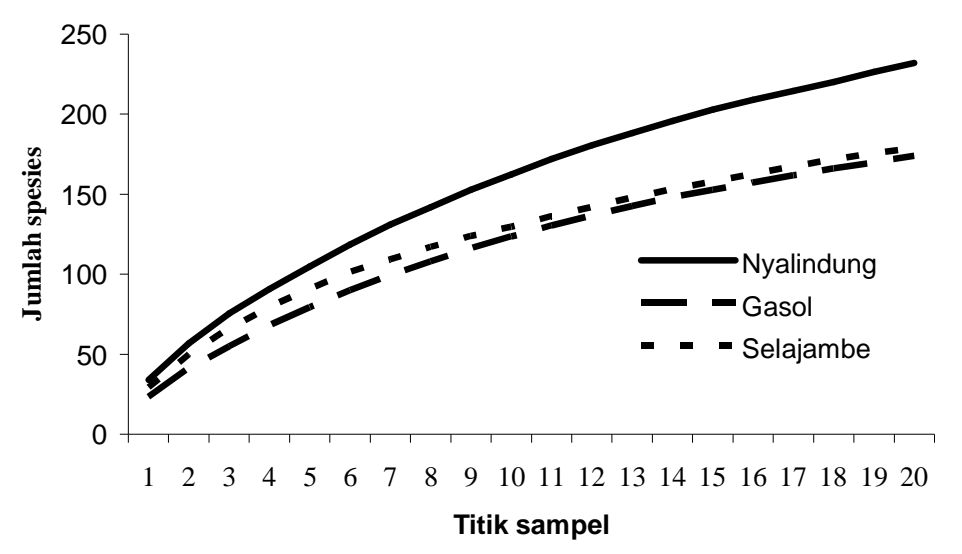

Gambar 1. Kurva akumulasi spesies Hymenoptera parasitoid pada pertanaman padi di ketiga lanskap berdasarkan data hasil pengacakan dengan program EstimateS 6.0b1. 


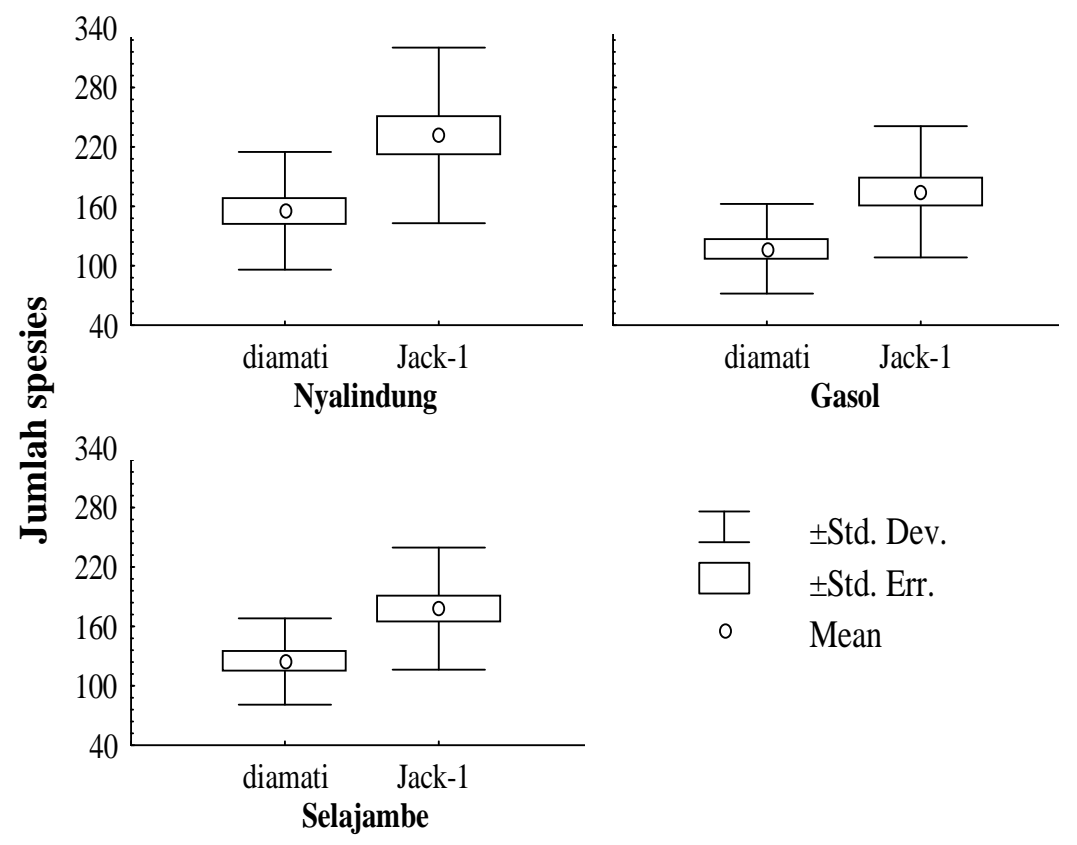

Gambar 2. Jumlah spesies Hymenoptera parasitoid pada pertanaman padi di ketiga lanskap berdasarkan data pengamatan dan Jackknife-1 estimator dengan program EstimateS 6.0b1.

Dengan demikian, belum optimalnya jumlah spesies Hymenoptera parasitoid yang dikumpulkan kemungkinan disebabkan oleh jumlah sampel (20 sampel per lanskap) dan alat yang digunakan untuk koleksi serangga belum optimal. Karena alasan teknis Malaise traps tidak digunakan dalam penelitian ini, padahal alat ini cukup efektif untuk menangkap Hymenoptera yang aktif terbang (Noyes, 1989; Pickering dan Sharkey, 1995; Rizali et al., 2000). Banyak ahli ekologi yang tidak setuju dengan Jackknife estimator diantaranya adalah Heltshe dan Forrester (1983b dalam Krebs, 1999) karena estimasi kekayaan spesies dalam komunitas dengan Jackknife estimator cenderung bias positif atau lebih tinggi (overestimate). Tetapi, Palmer (1990 dalam Krebs, 1999) mengemukakan bahwa Jackknife estimator lebih akurat dari delapan estimator lain yang dia gunakan.

Kekayaan, Keanekaragaman dan Kemerataan Spesies Hymenoptera Parasitoid. Keanekaragaman habitat dan struktur lanskap berpengaruh terhadap kekayaan, keanekaragaman dan kemerataan spesies Hymenoptera parasitoid. Pada Gambar 3 terlihat bahwa kekayaan dan keanekaragaman spesies Hymenoptera parasitoid lebih tinggi di lanskap Nyalindung daripada lanskap Gasol dan Selajambe, sedangkan kemerataan spesiesnya lebih rendah daripada kedua lanskap tersebut. Lebih jauh pada Gambar 3 terlihat bahwa kekayaan, keanekaragaman, dan kemerataan spesies Hymenoptera parasitoid antara lanskap Gasol dan Selajambe berbeda tidak nyata. Hal ini karena struktur lanskap Gasol dan Selajambe hampir sama yaitu padi monokultur, sehingga keanekaragaman spesies Hymenoptera parasitoid kedua lanskap tersebut tidak berbeda nyata. Nilai keanekaragaman spesies adalah resultante dari nilai kekayaan dan kemerataan spesies (Ludwig dan Reynolds, 1988). Dengan demikian jelas bahwa tidak berbedanya keanekaragaman spesies pada lanskap Gasol dan Selajambe karena kekayaan dan kemerataan spesiesnya juga tidak berbeda. Pola yang sama juga ditemukan oleh Suana (2004) pada keanekaragaman laba-laba pada ketiga lanskap tersebut.

Lanskap Nyalindung yang terdiri atas eksosiem padi, sayur-sayuran dan tumbuhan liar membentuk struktur lanskap yang lebih kompleks daripada lanskap Gasol dan Selajambe. Habitat-habitat tersebut menyediakan berbagai sumberdaya seperti inang alternatif, makanan serangga dewasa seperti serbuk sari dan nektar, dan habitat tanaman lain sebagai tempat berlindung parasitoid. Semua sumberdaya tersebut hanya diperoleh pada sistem pertanian 


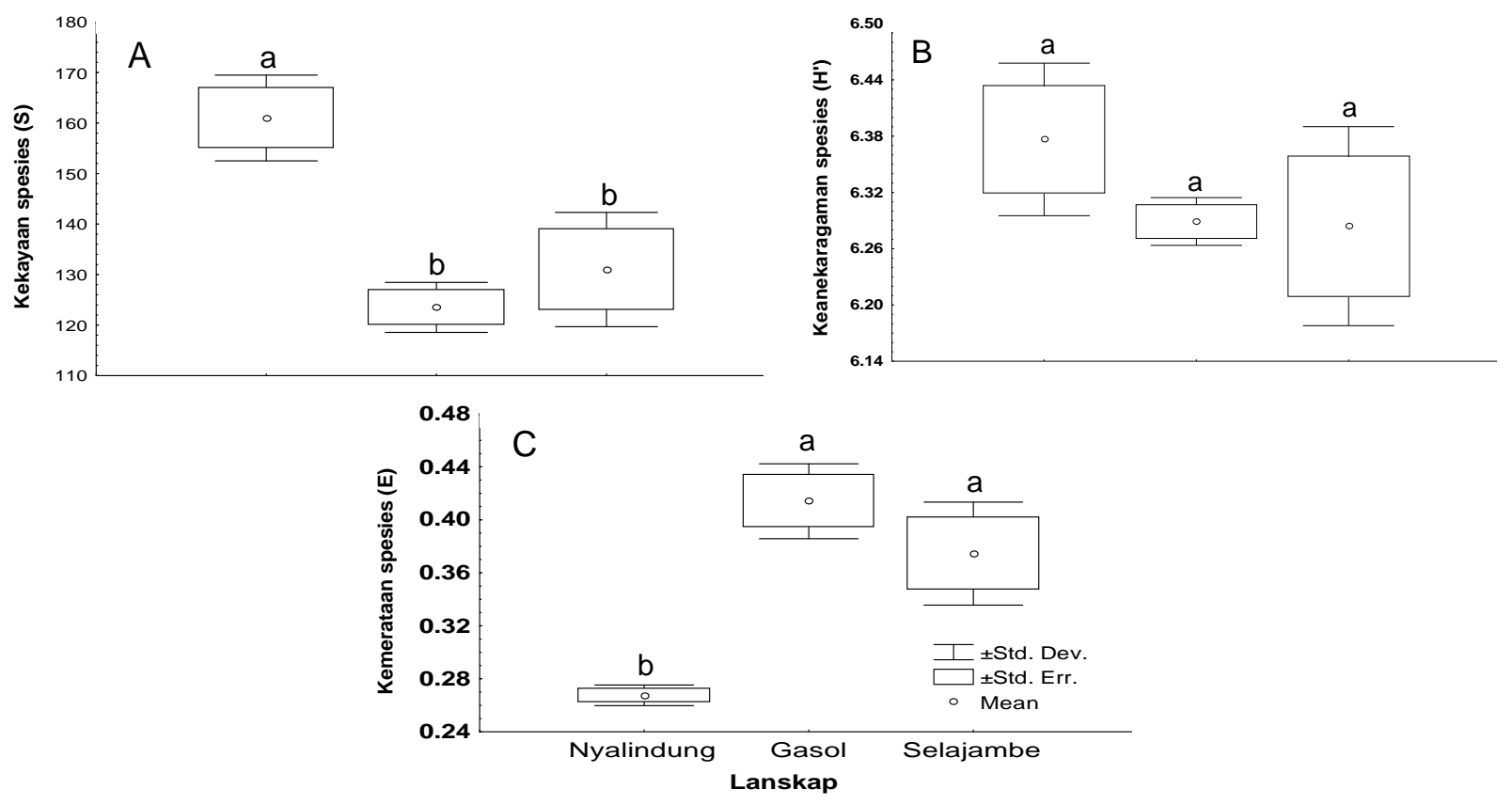

Gambar 3. Kekayaan (A), keanekaragaman (B) dan kemerataan spesies (C) Hymenoptera parasitoid pada pertanaman padi di lanskap Nyalindung, Gasol dan Selajambe

polikultur yang menjamin kontinuitas ketersediaan makanan dan iklim mikro yang sesuai bagi kelangsungan hidup dan keanekaragaman Hymenoptera parasitoid. Hasil yang sama juga pernah dilaporkan Heong et al. (1991) di Filipina bahwa keanekaragaman parasitoid pada pertanaman padi polikultur di Kiangan lebih tinggi daripada pertanaman padi monokultur di Bayombong.

Kemerataan spesies dalam komunitas Hymenoptera parasitoid di lanskap Nyalindung jauh lebih kecil dari lanskap Gasol dan Selajambe. Hasil ini menunjukkan bahwa kelimpahan spesies dalam komunitas Hymenoptera parasitoid di lanskap Nyalindung tidak merata. Dengan kata lain ada satu atau dua spesies yang sangat dominan pada lanskap tersebut. Hal ini dapat dilihat pada Tabel 2, kelimpahan relatif famili Eulophidae, Encyrtidae dan Scelionidae pada lanskap Nyalindung jauh lebih tinggi dari famili lainnya, sedangkan di lanskap Gasol dan Selajambe kelimpahan relatif masing-masing famili relatif tidak berbeda jauh, sehingga kemerataan spesies di lanskap Gasol dan Selajambe lebih tinggi dari lanskap Nyalindung (Gambar 3). Dengan demikian dapat dikatakan indeks kemerataan spesies (E) sangat sensitif terhadap kelimpahan spesies di dalam sampel (Magurran, 1988). Nilai kemerataan spesies akan cenderung menuju nol apabila komunitas tersebut didominasi oleh satu spesies (Heong et al., 1991).

Keanekaragaman, kekayaan dan kemerataan spesies Hymenoptera parasitoid cenderung lebih tinggi pada musim kemarau daripada musim hujan (Gambar 4). Demikian juga kelimpahan inang terutama Homoptera dan Lepidoptera lebih tinggi pada musim kemarau daripada musim hujan (Gambar 5). Hasil yang mirip juga ditemukan oleh Irsan (2004) bahwa kelimpahan populasi kutudaun Myzus persicae (Sulzer) (Homoptera: Aphididae) lebih tinggi pada musim kemarau daripada musim hujan. Hal ini berkaitan dengan kondisi tanaman inang yang mengalami kekurangan air pada musim kemarau. Kondisi seperti ini mengganggu proses metabolisme nitrogen tanaman dan menyebabkan terjadi hidrolisis protein, sehingga konsentrasi asam amino meningkat di dalam tanaman (Mattson et al., 1987; Brodbeck dan Strong, 1987). Peningkatan konsentrasi asam amino dalam tanaman menguntungkan bagi serangga herbivor terutama yang menghisap cairan tanaman seperti ordo Homoptera (Mattson et al., 1987). Peningkatan kelimpahan serangga herbivor pada musim kemarau berkorelasi dengan kosentrasi asam amino dalam tanaman inang (Brodbeck dan Strong, 1987). Dengan demikian peningkatan keanekaragaman Hymenoptera parasitoid pada musim 
$\square$ musim hujan

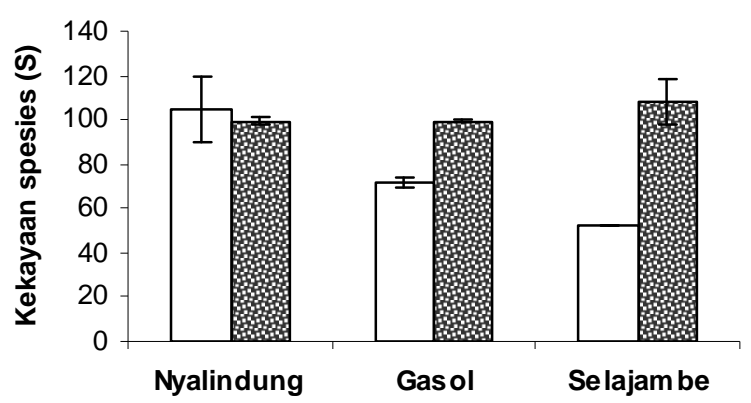

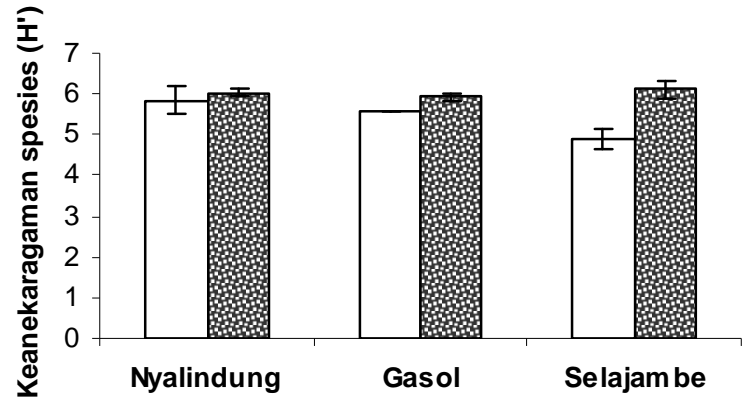

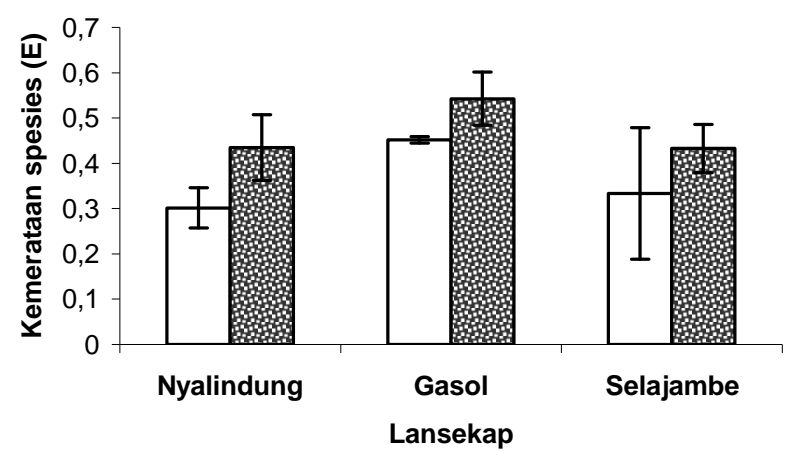

Gambar 4. Kekayaan, keanekaragaman dan kemerataan spesies Hymenoptera parasitoid pada musim hujan dan kemarau di ketiga lanskap

$\square$ musim hujan $\quad \square$ musim kemarau

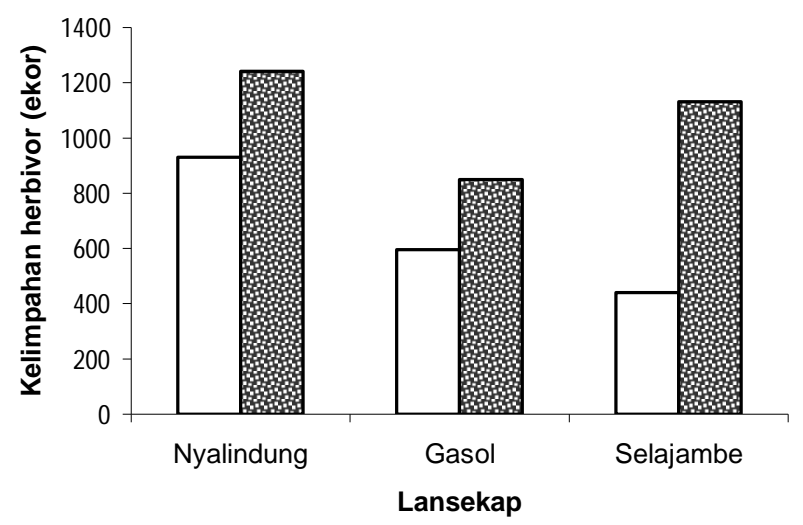

Gambar 5. Kelimpahan herbivor (Homoptera dan Lepidoptera) pada musim hujan dan kemarau. 
kemarau kemungkinan erat kaitannya dengan peningkatan kelimpahan herbivor tersebut. Hal ini dapat dilihat pada Gambar 6, yang memperlihatkan bahwa peningkatan kekayaan spesies Hymenoptera parasitoid pada musim kemarau berkorelasi positif dengan peningkatan kelimpahan herbivor tertentu seperti Homoptera dan Lepidoptera.

\section{Analisis Kesamaan Komunitas Hymenoptera} Parasitoid. Hasil pengelompokan komunitas Hymenoptera parasitoid untuk ketiga lanskap dapat dilihat pada Gambar 7. Terdapat dua kelompok besar dengan tingkat kemiripan $51 \%$. Kelompok pertama, yaitu lanskap Nyalindung terdiri atas lokasi N1 dan N2 (transek 1 dan 2) dengan tingkat kemiripan komunitas 56\%. Kelompok kedua, yaitu lanskap Gasol dan Selajambe dengan tingkat kemiripan komunitas 53\%. Tingkat kemiripan di dalam lanskap Gasol antara lokasi G1 dan G2 (transek 1 dan 2) adalah $63,5 \%$ dan di dalam lanskap Selajambe antara lokasi S1 dan S2 (tansek 1 dan 2) adalah $59 \%$.

Hasil analisis kelompok menunjukkan bahwa tingkat kemiripan komunitas Hymenoptera parasitoid pada lanskap Gasol dengan Selajambe lebih tinggi daripada dengan lanskap Nyalindung. Hal ini disebabkan oleh ekosistem di lanskap Gasol hampir sama dengan lanskap Selajambe yaitu pertanaman padi monokultur. Menurut Root dan Godfray (2000) pengelompokan komunitas parasitoid terutama dipengaruhi oleh tanaman makanan inang. Sato et al. (2002) menambahkan bahwa pengelompokan komunitas parasitoid tidak hanya ditentukan oleh tanaman makanan inang tetapi juga oleh lokasi geografinya.

Ekosistem di lanskap Gasol dan Selajambe didominasi oleh pertanaman padi monokultur, sehingga komposisi Hymenoptera parasitoid penghuni ekosistem tersebut hanya terdiri atas parasitoid serangga hama padi. Lanskap Nyalindung terdiri atas berbagai ekosistem (padi dan sayuran) dan memungkinkan terjadinya migrasi/aliran spesies antara ekosistem tersebut. Jadi komunitas Hymenoptera parasitoid pada ekosistem padi di lanskap Nyalindung tidak hanya terdiri atas spesies parasitoid penghuni ekositem padi, tetapi juga ekosistem sayuran. Hal ini yang menyebabkan tingkat kemiripan komunitas Hymenoptera parasitoid pada pertanaman padi di lanskap Nyalindung dengan lanskap Gasol lebih rendah, sungguhpun jarak lokasi Nyalindung dan Gasol lebih dekat $( \pm 15 \mathrm{~km})$ daripada jarak lokasi Gasol dan Selajambe $( \pm 40 \mathrm{~km})$.

\section{SIMPULAN}

Kekayaan spesies Hymenoptera parasitoid yang dikoleksi pada pertanaman padi sekitar $70 \%$ dari spesies yang ada berdasarkan Jacknife-1 estimator. Dengan demikian peluang untuk memperoleh jumlah spesies yang lebih banyak masih ada, dilihat dari kurva akumulasi spesies yang masih meningkat. Lanskap Nyalindung dengan struktur lanskap yang lebih kompleks memiliki kekayaan dan keanekaragaman spesies Hymenoptera parasitoid yang lebih tinggi daripada lanskap Gasol dan Selajambe. Dengan demikian dapat dikatakan stuktur lanskap pertanian di DAS Cianjur mempengaruhi keanekaragaman Hymenoptera parasitoid. Kekayaan, keanekaragaman dan kemerataan spesies Hymenoptera parasitoid pada musim kemarau lebih tinggi daripada musim hujan. Tingkat kemiripan komunitas Hymenoptera parasitoid pada pertanaman padi di lanskap Gasol dengan lanskap Selajambe lebih tinggi yaitu 53\% daripada dengan lanskap Nyalindung $51 \%$.

\section{DAFTAR PUSTAKA}

Brodbeck, B. \& D. Strong. 1987. Amino acid nutrition of herbivorous insects and stress to host plants. Pages 347-363 in: Brodbeck B. \& D. Strong, eds. Insect Outbreaks. Academic Press. New York.

Colwell, R.K. \& J.A. Coddington. 1994. Estimating terrestrial biodiversity through extrapolation. Philosophical Transactions of Royal Society London 345: 101-118.

Colwell, R.K. 2000. Estimates: Statistical estimate of spesies richness and shared spesies from samples. www.viceroy.eeb.uconn.edu/estimates [16 Desember 2003].

Driesche, R.G. \& T.S. Bellows. 1996. Biological Control. Chapman \& Hall. New York.

Forman R.T.T. \& M. Godron. 1986. Landscape Ecology. John Willey and Sons. New York

Goulet, H. \& J.T. Huber. 1993. Hymenoptera of The World: An Identification Guide to Families. Research Branch Agriculture Canada Publication. Ottawa. 


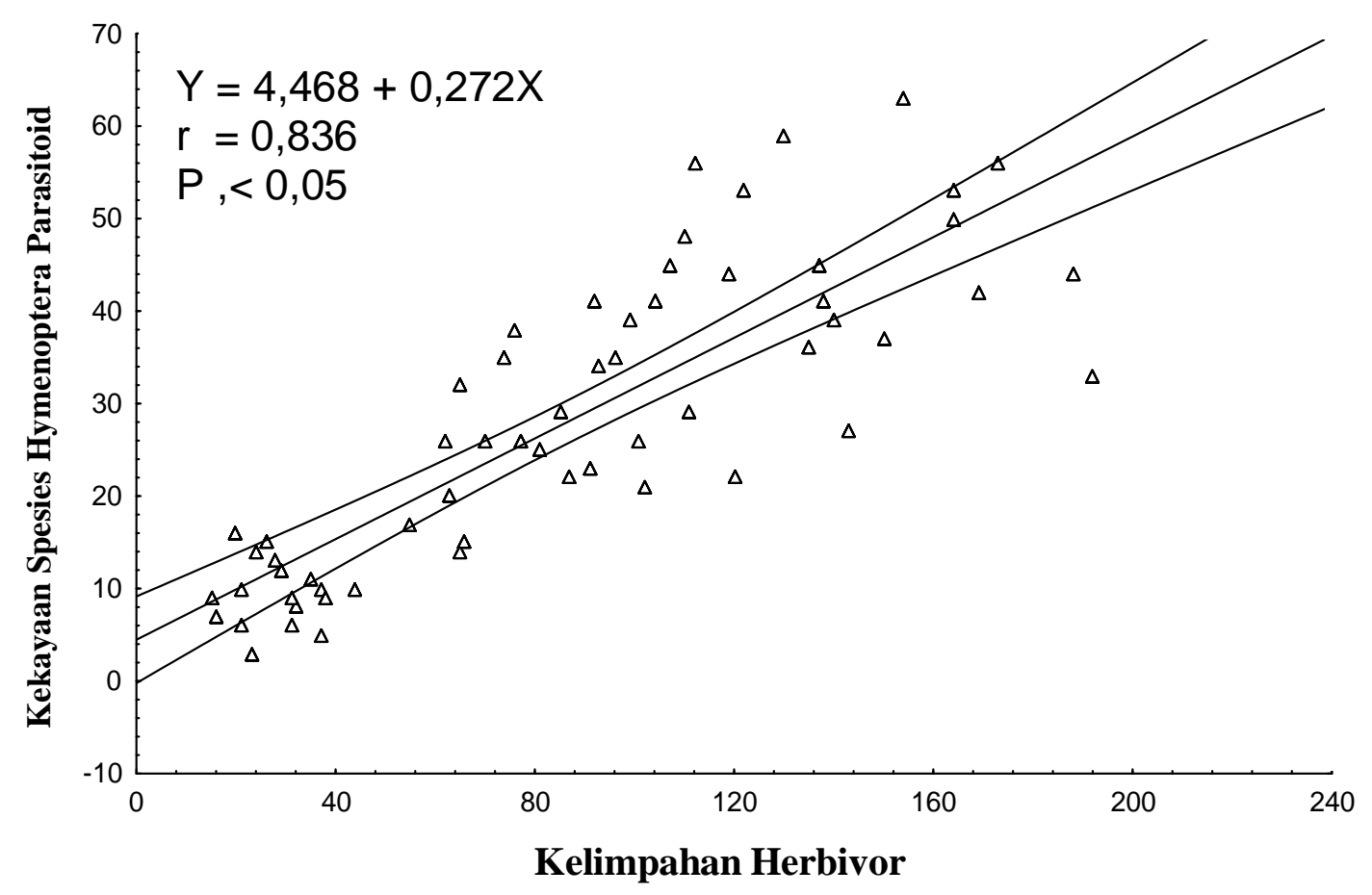

Gambar 6. Korelasi antara kelimpahan herbivor (Homoptera) dengan keanekaragaman Hymenoptera parasitoid pada musim kemarau

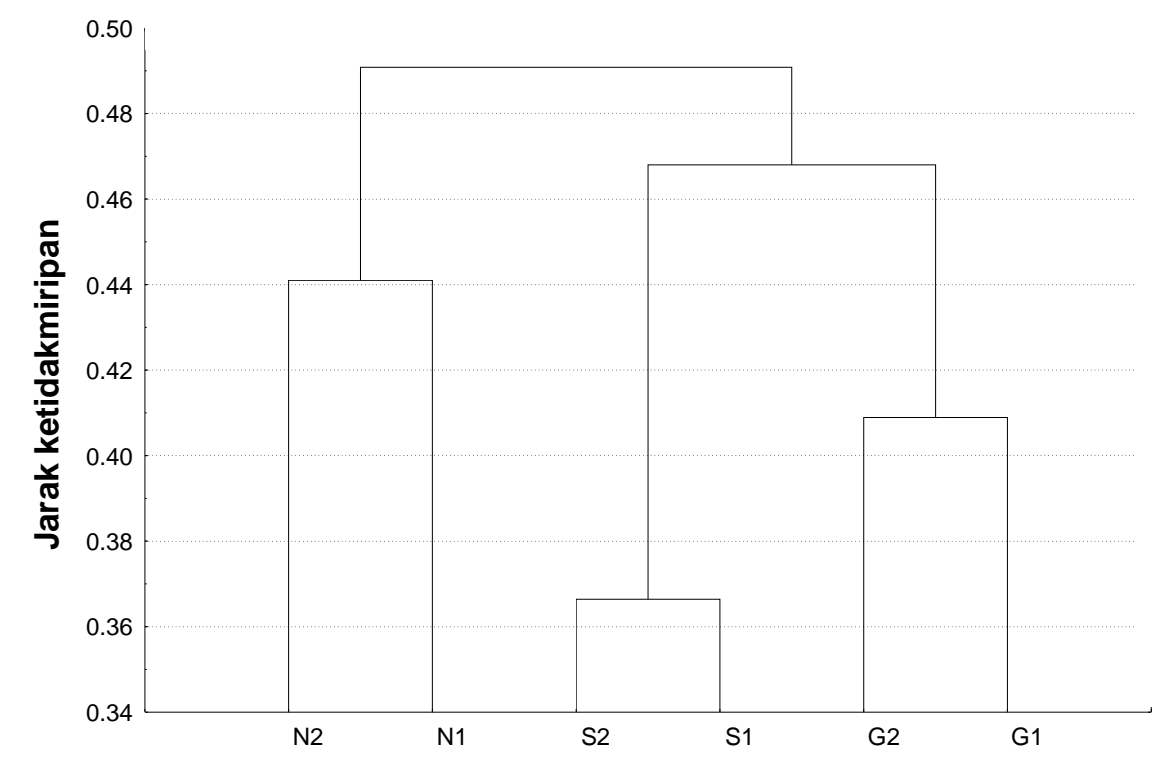

Gambar 7. Pengelompokan komunitas Hymenoptera parasitoid pada pertanaman padi di lanskap Nyalindung (N), Gasol (G) dan Selajambe (S) (huruf yang diikuti oleh angka 1 dan 2 adalah lokasi/transek 1 dan 2 untuk masing-masing lanskap) menggunakan Cluster analysis (UPGMA) dan jarak ketidakmiripan (dari nilai kemiripan Sorensen) 
Heong, K.L., G.B. Aquino \& A.T. Barrion. 1991. Arthropod community structure of rice ecosystem in the Philippines. Bull. Entomol. Res. 81: 407-416.

Irsan, C. 2004. Tumbuhan inang, parasitoid dan hiperparasitoid kutu daun Myzus persicae (Sulzer) (Homoptera: Aphididae) di sekitar Bogor dan Cianjur. [Disertasi]. Sekolah Pascasarjana Institut Pertanian Bogor. Bogor.

Krebs, C. J. 1999. Ecological Methodology. Second Edition. An imprint of Addison Wesley Longman, Inc. New York.

Krebs, C. J. 2000. Program for Ecological Methodology [software]. Second Edition. An imprint of Addison Wesley Longman, Inc. New York.

Kruess A \& T. Tscharntke. 1994. Habitat fragmentation, species loss, and biological control. Science 264: 1581 - 1584.

Kruess, A. \& T. Tscharntke. 2000. Spesies richness and parasitism in a fragmented landscape: experiments and field studies with insects on Vicia sepium. Oecologia 122: 129-137.

Kruess, A. 2003. Effects of landscape structure and habitat type on a plant-herbivore-parasitoid community. Ecography 26: 283-290.

LaSalle, J. 1993. Parasitic Hymenoptera, biological control and biodiversity. Pages $197-215$ in: LaSalle, J. \& I.D. Gaul, eds. Hymenoptera and Biodiversity. C.A.B. International. London.

Ludwig, J.A. \& J. F. Reynolds. 1988. Statistical Ecology. John Wiley \& Sons. New York.

Magurran, A.E. 1988. Ecological Diversity and Its Measurement. Chapman and Hall. London.

Mahrub, E. 1998. Struktur komunitas artropoda pada ekosistem padi tanpa perlakuan pestisida. J. Perlindungan Tanaman Indonesia 1: 19-27.

Marino, P.C. \& D.A. Landis. 2000. Parasitoid community structure: implications for biological control in agricultural landscapes. Pages 183 - 193 in: Ekbon, B., M.E. Irwin \& Y. Robert, eds. Interchanges of Insects between Agriculturan and Surrounding Landscapes. Kluwer Academic Publishers. Boston.

Matteson, W.J. \& R.A. Haack. 1987. The role of drought stress in provoking outbreaks of phytopagous insect. Pages 365 - 405 in: Brodbeck, B. \& D. Strong, eds. Insect Outbreaks. Academic Press. New York.

Noyes, J.S. 1989. A study of methods of sampling Hymenoptera (Insecta) in tropical rainforest, with special reference to the parasitica. J. Nature History 23: 285-298

Pickering J. \& M.J. Sharkey. 1995. Diversity and trophic interactions of parasitic wasps (Hymenoptera: Ichneumonidae) in Tropical lowland forests. http://www.diae.pik.uga.edu [20 januari 2004]

Rizali, A., D.Buchori \& H.Triwidodo. 2000. Keanekaragaman serangga dan peranannya di daerah persawahan di Taman Nasional Gunung Halimun, Desa Malasari, Kabupaten Bogor, Jawa Barat. Hlm. 175 - 183 dalam: Prosiding Simposium Keanekaragaman Hayati Artropoda pada Sistem Produksi Pertanian. Cipayung, 16-18 Oktober 2000.

Rizali, A., D. Buchori \& H.Triwidodo. 2002. Keanekaragaman serangga pada tepian hutanlahan persawahan: indikator untuk kesehatan lingkungan. Hayati 9: 41-48.

Rott, A.S., \& H.C.J. Godfray. 2000. The structure of a leafminer-parasitoid community. J. Anim. Ecol. 69: 274-289.

Spellerberg, I.F. 1995. Monitoring Ecological Change. Cambridge University Press. Melbourne.

Sato, H., Y. Okabayashi \& K. Kamijo. 2002. Structure and function of parasitoid assemblages associated with Phyllonorycter leafminer (Lepidopter: Gracillariidae) on decidous oaks in Japan. Environ. Entomol. 31(6): 1052-1061. 
Suana, I.W., D. Duryadi, D. Buchori, S. Manuwoto \& H. Triwidodo. 2004. Komunitas laba-laba pada lanskap persawahan di Cianjur. Hayati 11 (4): $145-152$.

[Statsoft] Statistical Software. 1997. Statistica for Windows 5.0 [Software]. Statsoft. Tulsa. van Emden, H.F. 1991. Plant diversity and natural enemy efficiency in agroecosystems. Pages 63 - 80 in: Mackkaue, M., L.E. Ehler \& J. Roland, eds. Critical Issues in Biological Control. Atheneum Press. Great Britain.

Yaherwandi, S. Manuwoto, D. Buchori, P. Hidayat \& L.B. Prasetyo. 2006. Analisis spasial lanskap pertanian dan keanekaragaman Hymenoptera di Daerah Aliran Sungai Cianjur. Hayati (in press edisi Desember 2006). 